\title{
LAURENCE BROWN
}

\author{
EXPERIMENTS IN INDENTURE: BARBADOS AND \\ THE SEGMENTATION OF MIGRANT LABOR IN \\ THE CARIBBEAN 1863-1865
}

In the summer of 1863 , over two thousand Barbadians traveled to the sugar plantations of St. Croix and Antigua under three-year contracts of indenture. ${ }^{1}$ Larger movements of migrant labor from Barbados flowed across the Caribbean during the nineteenth century. However, the migrants of 1863 were unique because their contracts mirrored those used to import Asian and African immigrants. This brief convergence between currents of regional migration and indentured immigration from outside the Caribbean is particularly significant as these two groups became increasingly segregated within the British West Indian sugar industry during the late 1860s (Rodney 1981:31-59). Caribbean historiography has rarely examined the changing relationship between these two flows of migrant labor, yet the emergence and rapid termination of projects for indentured Barbadian labor reveals much about the debates, conditions, and tensions within the island colonies that shaped the construction of indentured immigration during the middle of the nineteenth century. ${ }^{2}$

The re-emergence of indentureship in the postemancipation Caribbean was marked by considerable experimentation with both the terms and sources of migration between the 1830s and 1860s. In the first decade after the abolition of slavery, there was a proliferation of private and state-sponsored projects for immigrant labor which drew migrants from Europe, North America, Asia, and Africa (Laurence 1971). During this period, indentured immigrants were outnumbered by migrant workers from the Eastern

1. This paper has been considerably improved by the comments of Richard Allen and Barry Higman, as well as by discussions at the $34^{\text {th }}$ Annual Conference of the Association of Caribbean Historians in Nassau. I am also very grateful to Daryl Josiah and his family for their hospitality and help in Antigua, and to Kimberlee Armstrong and Pernille Røge for their assistance in Barbados and Denmark.

2. Roberts 1955; Johnson 1973; Rodney 1977; Marshall 1984.

New West Indian Guide / Nieuwe West-Indische Gids vol. 79 no. 1 \& 2 (2005):31-54 
Caribbean who were recruited, without long-term contracts, by the planters of Trinidad and British Guiana (Richardson 1980). However, the balance between these two currents of labor migration was reversed after the economic crisis of 1846 caused by the British repeal of protective tariffs on West Indian sugar. As planters cut the wage-rates that had drawn regional migrants, colonial governments in the southern Caribbean became increasingly committed to long-term contract migration, and particularly to the indentureship of Africans seized by the British repression of the Atlantic slave trade. During the $1850 \mathrm{~s}$, India replaced Africa as the dominant source of indentured immigrants and the terms of service were lengthened and standardized, culminating with the peak of indentured immigration into the British West Indies in the early 1860s (Laurence 1965; Look Lai 1993:5261; Northrup 1995:21, 159-60).

Underpinning the multitude of projects for migrant labor during the midnineteenth century was the belief that population density was the central motor for plantation production. This nexus between population, land, and labor supply had been repeatedly articulated during the demographic debates of the early $1800 \mathrm{~s}$ as population decrease became a symbol for abolitionists of the bankruptcy of West Indian slavery and as the expansion of the British empire in the Pacific and Asia fueled new theories about the nature of colonial settlement (Curtin 1955:134-35; Higman 1982). After emancipation in 1834, colonial officials and planter elites across the British West Indies sought to physically concentrate island populations within the plantation economy through legislation against internal or external migration, and through state-supported schemes for migrant labor. Population density on the islands was therefore far from simply a "geophysical fact," but emerged from the changing conflicts between planter interests, colonial authorities, and workers (Bolland 1981:614).

The fusion of colonial debates over population and migration was starkly articulated in 1863 when Barbados was wracked by labor unrest and food shortages. Mass emigration from the island was seen as both a temporary safety valve to alleviate social discontent and as a destablizing threat to plantation production. The speedy measures by Barbadian authorities to close off labor migration after the summer crisis, reveals the extent to which perceptions of overpopulation emerged from competing economic and political interests rather than demographic realities. Following the separate streams of Barbadian migrants across the Caribbean during this period highlights how colonial governments transposed indenture contracts from one immigration project to another. Yet, if indentureship threatened to become a common framework for migrant labor during the early 1860 s, such experiments were rapidly blocked by intercolonial rivalries over labor supply. These tensions between the sugar economies of the British West Indies were reinforced by differences in environment, technology, and capital which ultimately 
produced increasing economic specialization and ethnic differentiation of migrant labor in the region.

MALTHUS OR MIGRATION:

The POLITICS OF POPUlATION IN BARBADOS

The twenty-fifth anniversary of the abolition of slavery in the British West Indies was commemorated in London with a public meeting on August 1, 1859 addressed by the Governor of Barbados, Francis Hincks. In celebrating emancipation as an economic success in the Caribbean, Hincks (1859:1-2, 11) explicitly sought to support contemporary abolitionist campaigning in North America. He believed that the fall in West Indian sugar production which had followed emancipation was to be blamed on poor policy by colonial elites, rather than the moral character of the former slaves. His speech in London drew on the position Hincks had expressed a few months earlier in Barbados to the visiting New York Times journalist, William Sewell,

Governor Hincks is of the opinion that there is a sufficiency of labor in many of the colonies, and that the resort to indiscriminate Coolie immigration is unnecessary and uncalled for. He thinks that this, next to slavery, is the most expensive kind of labor; one which it is impolitic to encourage when Creole labor can be procured by the inducements of higher wages and a more liberal tenure. (Sewell 1862:56-57)

Describing to his London audience how plantation production in Barbados had become more efficient with emancipation, Hincks $(1859: 10-11,28)$ rejected criticisms that this was solely due to the uniquely high population density of the island and argued that similar economic growth was possible for the rest of the region.

Throughout his London speech, Hincks drew on the survey of postemancipation labor conditions written by Sewell during the journalist's travels across the British West Indies in 1859. On his visit to Barbados, Sewell (1862:13, $17,27-28)$ praised the island as proving the profitability of free labor over slave production. During the $1820 \mathrm{~s}$, Barbados averaged sugar exports of 11,946 tons per year, while by the 1850 s these had almost tripled to 31,261 tons per year as planters developed more intensive methods of cultivation. ${ }^{3}$ Sewell (1862:31) argued that this dramatic increase in the island's sugar exports was primarily due to the island's high population density which guaranteed an abundant supply of labor, and he wrote that "to this cause more,

3. From the mid-1840s Barbadian planters invested heavily in guano to fertilize their sugar crops. However, such agricultural improvements depended on cheap labor for constant replanting (Sewell 1862:15, 26, 62-63; Deerr 1949:193-94; Sheridan 1989:72-77). 
perhaps, than to any other, she owes her present wonderful prosperity." With over 150,000 inhabitants, and an estimated 95 percent of her 166 square mile surface area devoted to agriculture, Barbados appeared almost "a perfect garden," the model colonial export economy (Sewell 1862:33-34). Yet Sewell (1862:58) also recognized that such economic gains came at a social cost, as he described the island's "overstocked and imprisoned population, compelled to work on such terms as the planters may dictate."

The intensification of sugar production in postemancipation Barbados that so impressed Sewell in 1859 rested on exceedingly fragile foundations. Arguing that agricultural labor in Barbados had always been abundant, Sewell (1862:33) wrote that "partly from an aversion of the negro to leave his home, partly from his fear, still easily excited, of being sold into slavery, no material emigration from the island has ever taken place." In fact, during the decade that immediately followed emancipation, there had been a considerable exodus from the island to Trinidad and British Guiana, despite the enactment by the Barbados Assembly of legislation restricting emigration in 1839 and 1840. While these laws were framed in the language of protecting workers from exploitative immigration agents and of saving dependents from abandonment, their unstated intention was to deliberately perpetuate the island's high population density to support its plantation economy (Roberts 1955:247-49; Richardson 1980:398-400). Postemancipation productivity on the plantations of Barbados had been based on reducing labor costs (through linking wages and rent for residence) and expanding the cultivation of sugarcane on estate land at the expense of provision grounds (Levy 1980:126-27). This potentially volatile combination of limited labor mobility, low wages, and the reliance on imported foodstuffs exploded in the summer of 1863 when a prolonged and extreme drought dramatically pushed plantation laborers to the brink of subsistence.

In the words of the governor of Barbados, James Walker, 1863 was a "year of hardship and distress to all classes." ${ }^{4}$ However, the crisis fell most heavily on the laboring poor, due to the "long and severe drought which not only brought about a scarcity of native provisions but rendered agricultural employment from the state of the soil both difficult and valueless." 5 By July 1863 , faced with a reduced crop, estates had cut back their labor forces to only employing workers for a few days a week or long enough to cover the rents on estate tenantries. ${ }^{6}$ As one local journalist noted, "in many parts of the country the people are starving: and where a labouring man is compelled to receive nine cents a day and pay his rent out of it, and support his family,

4. Minutes of the House of Assembly (henceforth MHA), October 6, 1863, Black Rock, Barbados National Archives, p. 62.

5. Walker to Newcastle, October 21, 1863, CO 28/197, National Archives, London.

6. The Times (Bridgetown), July 10, 1863, p. 3. 
it can easily be judged what their condition is." F Faced with such demands, the existing system of parish-based poor relief broke down as the vestries of St. Philip and St. Lucy were forced to seek emergency funds from the House of Assembly. ${ }^{8}$ The American Civil War had already created a shortage of imported foodstuffs, while the only local provisions that survived the drought were potatoes, whose scarcity across the island meant that the small amount of produce available was largely reserved for the estates. ${ }^{9}$ As wages and provision supplies shrank dramatically over the summer, so food prices, unemployment, and social unrest soared.

These extreme conditions of privation and semi-starvation fueled a massive upsurge in petty crime, especially in raids on the provision grounds of the estates. There were also open confrontations between the militia, police, and crowds at the beginning of July 1863 when a shipwreck on the coastline of St. Phillip seemed to offer a providential source of food, and at the end of the same month police opened fire on a crowd gathered during a cane fire at the Mount Hillaby Estate. ${ }^{10}$ But it was the night raids on plantation provision grounds and storehouses by groups of laborers that generated the greatest "feeling of alarm and insecurity" amongst the authorities. ${ }^{11}$ As Governor Walker recognized, labor protest against cuts in wages, employment and the redefinition of task work became mixed with crimes of starvation. ${ }^{12}$ In response, groups of special constables were drafted to protect certain estates and organized into night patrols of the central parishes on the island. Repression dramatically doubled the island's prison population to 650 by the end of summer, the vast majority of whom had been sentenced for raids on plantations' provision grounds. ${ }^{13}$ On July 28, 1863 the Governor's Council and House of Assembly unanimously voted a special bill which specified the punishment of flogging for adult males if they were part of a group of three or more that sought to "enter upon any cultivated land for the purpose of committing any deprivation or outrage." 14

7. The Times, July 24, 1863, p. 3; Sewell had earlier estimated that an average agricultural wage in Barbados was 22 to $25 \mathrm{c}$ a day (Sewell 1862:146).

8. MHA, June 23, 1863, pp. 43-44; MHA, July 28, 1863, pp. 53, 56.

9. The Times, July 10, 1863, p. 3 .

10. The Times, July 7, 1863, p. 3; The Times, July 10, 1863, p. 2. (Carter 1996; Beckles 2004:95-180).

11. Walker to Newcastle, August 9, 1863, CO 28/196.

12. Walker to Newcastle, July 25, 1863, CO 28/196; Walker to Newcastle, August 9, 1863, CO 28/196.

13. MHA, October 6, 1863, p. 62; Walker to Cardwell, October 31, 1864, CO 28/199; Mundy to Cardwell, October 18, 1865, CO 28/201.

14. Walker to Newcastle, August 9, 1863, CO 28/196. 
Amidst this summer of crisis, migration was seen by the authorities, the local press, and laborers of Barbados as an important means of relief. An editorial in The Times (Bridgetown) argued,

\begin{abstract}
That the majority of our labouring population are enduring great privation at the present time is a fact - that few, we believe, will be found bold enough to deny; and having no prospect of improvement, but the contrary; in view of the rapidity with which they multiply, some means might be devised by which their condition might be improved, and the destitution which prevails among them diminished... We have more than once advocated the emigration of a few thousands of the population - the advantage thereby acruing to society and the people themselves would be incalculable, whilst the planting interest would not suffer in consequence. There are many people who cannot find employment, these may emigrate. ${ }^{15}$
\end{abstract}

On the same page as the above statement, the journal noted the spontaneous migration by those who could afford passages to St. Vincent, Trinidad, and British Guiana. ${ }^{16}$ Others without such resources sought an escape from the drought through enlistment in the West Indian Regiment, which resulted in the local garrison being swamped by applicants. ${ }^{17}$ However, such movements were transformed by the end of that summer with the establishment of organized recruitment schemes that provided new opportunities for emigration to those without the means to cover the costs of sea passage.

\title{
BARBADIAN INDENTURED IMMIGRATION TO \\ ST. CROIX AND ANTIGUA
}

In the years immediately preceding the drought of 1863 , Barbadian authorities had actively sought to prevent the foreign recruitment of agricultural laborers. In early September 1860, an immigration agent for St. Croix began advertising in rural districts across Barbados promising free passage and a signing-on bonus (bounty) of up to five dollars a head which quickly drew two hundred workers who sought to emigrate. ${ }^{18}$ There was enthusiasm despite rumors that migrants would be sold back into slavery, and in the face of considerable official pressure which went as far as having police board immigrant ships, as well as a direct request from the Barbados government to the authorities in St. Croix to suspend recruiting. Governor Hincks of Barbados opposed such emigration, citing concerns for the migrant's interests, as the exploitative actions by recruiting agents would render them "apprentices for

15. The Times July 17, 1863, p. 2.

16. The Times July 17, 1863, p. 2.

17. The Times, July 10, 1863, p. 3; The Times, July 24, 1863, p. 3.

18. Hincks to Newcastle, September 8, 1860, CO 28/191. 
life." 19 However, at the same time as Hincks so actively opposed the largescale migration of black laborers, he sought to encourage emigration from Barbados by poor whites due to fears about their economic and physical decline after emancipation (Watson 2000). For the governor and the colonial government, migration was a means of relief for those sections of Barbadian society that fell outside the plantation economy, but it was not to be extended so as to directly challenge the labor relations within the sugar industry.

The resistance of the ruling elite of Barbados to the organized emigration of agricultural workers contrasted with the explicit commitment of imperial authorities to labor mobility (Roberts 1955:248-49; Marshall 1984:6-10). At the start of 1861, the Colonial Office in Britain accepted the organization of regional immigration to St. Croix, in the face of considerable opposition by Barbadian authorities. ${ }^{20}$ By the time this decision reached Barbados, the recruiting agent for St. Croix, Barbadian Charles Bryan, was no longer on the island, having been threatened with prosecution under the immigration laws of $1840 .{ }^{21}$ In late 1862 , Bryan returned to the island and attempted to renew the recruitment of migrants, however, the new governor of Barbados, James Walker, reversed London's policy by arguing that this migration scheme was based on a system of bounties which had been absolutely rejected by Britain in $1846 .{ }^{22}$

Paralleling its failed attempts to recruit agricultural laborers from Barbados, the St. Croix government was also lobbying in Washington to obtain black migrant labor from America and in London for access to indentured immigration from British India. ${ }^{23}$ Slavery had been abolished in the Danish West Indies in 1848, however this had been followed by a twelveyear period of apprenticeship that had maintained workforces on the sugar estates until the early 1860s. Fearing severe labor shortages once the island's population was no longer legally tied to the plantations, St. Croix authorities received approval for indentured Indian immigration in early 1863 after extensive negotiations in Britain. Under indentures for five years, 321

19. Hincks to Newcastle, September 6, 1860, CO 28/191.

20. Hincks to Newcastle, January 10, 1861, CO 28/192; Newcastle to Hincks, February 13, 1861, CO 28/192.

21. Barbadian authorities admitted that the Act of 1840 only provided a penalty for "falsehoods" by immigration agents, and therefore there was no legal penalty for them to enforce against Bryan's actions which they had declared illegal (Hincks to Newcastle, September 8, 1860, CO 28/191).

22. Walker to Newcastle, October 24, 1862, CO 28/195.

23. "Employment of Laborers of African Extraction in the Island of St. Croix: Correspondence between the State Department of the United States and the Chargé d'affaires of Denmark," Washington, 1862, Schomburg Center for Research in Black Culture, New York. 
migrants left India in late February 1863, just before the close of the official recruiting season (Sircar 1971:136-42). ${ }^{24}$ These pre-existing projects for migrant labor resulted in a rapid response by St. Croix's government to news of the summer crisis in Barbados.

The drought and disorder of 1863 forced Barbadian authorities to reverse their earlier opposition to emigration to St. Croix, thought significantly the renewal of labor recruiting came not from St. Croix's official agent, but from Barbadian J.H. Shannon who began advertising for agricultural laborers on his own initiative in mid-July 1863. Shannon informed potential migrants that he had chartered a schooner, the Gold Hunter, "to take them free of all expense for passage to said Island [St Croix], there to make their own terms." 25 A fortnight later, Charles Bryan returned to Barbados and set up his own recruitment office in Bridgetown on the same block of Prince William Henry Street as Shannon. Rather than simply providing free passage, Bryan restarted his earlier efforts in which migrants were paid bounties for agreeing to three-year contracts. ${ }^{26}$ With an official system of contract immigration established by St. Croix, Shannon moved his efforts at the end of August 1863 to recruiting workers for Antigua on behalf of that colony's government.

Like St. Croix, Antigua's swiftly constructed scheme for Barbadian emigration emerged from a series of earlier projects and negotiations over immigrant labor. In 1834, Antigua was unique in the British West Indies for enacting immediate emancipation due to the confidence of its plantocracy in controlling the island's working population (Hall 1971:17-31). By the time of the 1846 crisis over sugar duties, such beliefs had been replaced by complaints of labor shortage, which led Antiguan planters to join the demands of other West Indian colonies for indentured immigration (Hall 1971:45; Dyde 2000:162). A decade later, the rising sugar prices of the late 1850s fueled intensifying calls for migrant labor (Deerr 1950:531).

Visiting Antigua in early 1860, William Sewell $(1862: 145,154)$ had ambivalently reported that despite the island's population of over thirty-five thousand people, local authorities claimed that there was a labor shortage with only six thousand field laborers. He wrote that,

Small as Antigua is, there are parts of the island where labor is abundant and other parts where labor is scarce. The planters are seeking to introduce coolies. They are in need, they say, of 2000 laborers; and it is to be presumed that they understand their own wants (Sewell 1862:152).

24. In British India, the state-sanctioned recruitment season for migrant labor to the Caribbean was between September and February (Tinker 1993:137).

25. The Times, July 17, 1863, p. 2.

26. Birch to Walker, August 15, 1864, CO 28/198. 
While Sewell $(1862: 148,156)$ had enthusiastically endorsed the results of indentured Indian immigration in Trinidad, he noted that in Antigua there had been little attempt to recruit workers from the local population, particularly the fifteen thousand-strong residents of the island's free villages. At the same time that Sewell was writing, acting Antiguan governor, Edward Eyre, was enthusiastically endorsing overseas labor as necessary for continued sugar production and in the best interests of the colony. ${ }^{27}$

Eyre had been a temporary replacement for Governor Ker Baillie Hamilton, who upon his return to Antigua found himself in opposition to the House of Assembly's strengthening commitment to immigration. Hamilton made his endorsement of indentured immigration from Africa and Asia conditional on reforms for the island's Creole population, particularly on the local Assembly funding improved medical and municipal services. ${ }^{28}$ While these reforms were reluctantly enacted by the assembly, Hamilton publicly declared in September 18962 that

\begin{abstract}
Notwithstanding the urgent sentiments expressed in the House of Assembly for the reception of Immigrants, I am of the opinion that Immigration to this Island cannot be carried out to any large extent. The Island is subject to drought - that of 1860 was remarkable for its long continuance - and at such times the present population is superabundant and the lower orders are subject to great privation. The improved economic management of Plantations and the skillful application of labor with the employment of modern implements of husbandry are likely to do more for the Colony, already supplied with a sufficient population and where labor is cheap, that the costly experience of introducing foreign laborers who are not likely to do more work or demand less wages than the native Peasantry. ${ }^{29}$
\end{abstract}

Hamilton's opposition to indentured immigration, which was decisive in the Colonial Office rejecting the colony's demand for liberated African migrants, earned him the opprobrium of the local planters who argued in reply "there may be a redundancy of population and yet a deficiency of labour." 30

In early 1862, the Antiguan legislature had passed an export tax to fund indentured immigration, which within eighteen months had raised eight-

27. "To His Grace the Duke of Newcastle, KG, Her Majesty's Principal Secretary of State for the Colonies. The Memorial of the House of Assembly of Antigua" (hereafter "To the Duke of Newcastle"), May 1863, Codrington Papers, E 31, Antigua National Archives (hereafter ANA), p. 1.

28. "To the Duke of Newcastle," p. 3.

29. "To the Duke of Newcastle," p. 9; Hamilton also criticised the accommodation available on the estates as insufficient for native laborers and any potential indentured immigrants ("To the Duke of Newcastle," p. 10).

30. "To the Duke of Newcastle," pp. 13-14. 
and-a-half thousand pounds. ${ }^{31}$ Directly petitioning the Colonial Office for the importation of Indian immigrants, Antiguan planters were forced to postpone their recruitment of indentured immigrants at the end of 1862, owing to the insistence of authorities in Britain on legislative and financial provisions in case drought in Antigua threatened migrant employment. ${ }^{32}$ These delays in securing indentured immigration from Asia and Africa meant that Antiguan planters swiftly reacted to the crisis in Barbados during the summer of 1863 , and that they approached that migration in the same way as immigrants from outside the region.

In late July 1863, a three-member delegation from the legislature of Antigua visited Barbados seeking to recruit one to two thousand plantation laborers. ${ }^{33}$ Heading the delegation was Executive Council member Charles Eldridge, who reported that

\begin{abstract}
the opinion is pretty generally expressed that the people [of Barbados] will not go down to enter into contracts; and many persons apparently favourable to us suggest that we should place a small vessel on the berth for Antigua, making a nominal charge for passage money and leaving them free to make their own engagements in Antigua ... This plan, we cannot adopt. ${ }^{34}$
\end{abstract}

As a result, Antigua's immigration agent, J.H. Shannon, did not simply arrange passage for the migrants to negotiate their own employment as he had initially done for St. Croix, but rather advertised for workers and their families willing to contract themselves for three years in Antigua.

To make such terms more attractive, migrants were offered a signingon bounty of twenty-five dollars, a house, provision grounds, medical care, and regular wages of twenty cents per day. ${ }^{35}$ Merchants Ramsey, Elder and Co. guaranteed to potential emigrants a free transfer of remittances between their stores in Antigua and Barbados. While the terms of the contract broadly mirrored those of indentured immigrants from Asia and Africa, the offer of individual houses and land plots in Antigua and St. Croix contrasted to

31. A third of the funds for immigration were to come from an export tax levied on sugar and rum, another third from contributions from the colonial government, and a third direct from the employers of the immigrants ("To the Duke of Newcastle," pp. 2-3, 20). 32. Rodgers to Garraway, December 29, 1862, Codrington Papers, E 31, ANA. It was not until the end of June 1863 that Lord Newcastle fully endorsed indentured immigration to Antigua (Newcastle to Hill, June 30, 1863, Leeward Island Dispatches, 1863, ANA).

33. Walker to Newcastle, August 9, 1863, copy July 21, 1863, Eldridge to Walker, CO 28/196; Walker to Newcastle, August 9, 1863, copy July 16, 1863, Hill to Walker, CO 28/196.

34. Antigua Times, August 1, 1863, p. 3.

35. The Times, August 28, 1863, p. 2; Walker to Newcastle, August 9, 1863, CO 28/196. 
the barracks accommodation and ration systems which were developed for indentured labor in British Guiana, Trinidad, and Cuba. The substantial signing-on bonus and the omission of any right to repatriation also differentiated the labor contracts offered to Barbadians from those of indentured Indian immigrants. Despite such differences, Antiguan planters described and saw Barbadian migrants as indentured laborers, even passing a law within a month of their arrival in Antigua to prevent the "clandestine departure and removal of indentured immigrants." 36

Given the social unrest of the summer, Governor Walker of Barbados was far more sympathetic to the Antiguan scheme than he had been to the earlier efforts of St. Croix. Walker informed the visiting Antiguan delegation that,

\begin{abstract}
If any of the laborers are discontented with their position or complain of a scarcity of employment, or imagine that they will better their condition by leaving the Island, they are at perfect liberty to do so, and the Executive will be very far from interposing any difficulty in their way.

On the contrary, if any of them decide to quit Barbados and seek their fortunes elsewhere, I should prefer to see them resort to a well established old British colony like Antigua with a soil and climate more congenial to them than can be the swampy lands of Demerara. ${ }^{37}$
\end{abstract}

Yet despite such proclamations, the Governor's Council in Barbados deliberately withheld from officially sanctioning the immigration schemes by St. Croix and Antigua, even as both colonies openly recruited Barbadian laborers. Far from migration being actively used by the Barbados government as a "means of immediate relief," its response to foreign recruiting efforts was far more hesitant, complex, and contradictory (Roberts 1955:252; Fletcher 1980).

As the Legislative Assembly of Antigua debated the importation of Barbadian laborers, at least one of its members recognized the ambivalence of authorities in Barbados to such emigration. Upon hearing the report of its delegation to Barbados, Thomas Foote, attorney for the Parham Hill plantation, commented that,

it would seem that the Planters of Barbados were indisposed to promote emigration from that Colony, and that judging from the remarks of $\mathrm{Mr}$ Walker, in an ordinary good season, the supposed superabundant population was not more than sufficient for their own agricultural wants. Remembering that there once existed a law in this Island to punish persons enticing people away from the Colony, it appears not the right thing to do to others what we did not like to be done to ourselves. ${ }^{38}$

36. The Times, September 12, 1863, p. 3.

37. Walker to Newcastle, August 9, 1863, copy July 22, 1863, Walker to Eldridge, CO 28/196.

38. Antigua Times, August 1, 1863, p. 3. 
In reply, Foote's colleagues in the Assembly mocked his scruples, especially given his recent willingness to employ Chinese immigrants who had been shipwrecked on neighboring Barbuda in May 1863 (Dyde 2000:165). While the Antiguan House of Assembly strongly endorsed Barbadian immigration, Foote had identified the population concerns which Barbados authorities would increasingly articulate from late 1863 as they attempted to stop the labor exodus from their island.

During the second week of August 1863, the first two boats for Antigua left Barbados carrying seventy-two emigrants, of whom over 90 percent were male. ${ }^{39}$ Their arrival was welcomed by the Antigua Times which called for a greater emphasis on family migration, as "the great want of this colony, certainly, is an accession of agricultural labor but we want at the same time, an enlarged permanent population, and in no way can this be better served than by encouraging the settlement of the Barbadians in families." 40 Such support for family migration was primarily motivated by the belief that it would limit labor mobility from the plantations and make migration more acceptable to authorities in Barbados who were concerned about the abandonment of dependent family members. ${ }^{41}$ The direct encouragement of family migration to Antigua had a significant impact on the composition of emigration from Barbados (see Table 1).

Table 1. Emigration from Barbados, Summer $1863^{42}$

\begin{tabular}{lrccc}
\hline & Total & Adult Male & Adult Female & \multicolumn{1}{c}{ Child } \\
\hline St. Croix & 1,091 & $701(64.3 \%)$ & $304(27.9 \%)$ & $86(7.9 \%)$ \\
Antigua & 806 & $396(49.1 \%)$ & $196(24.3 \%)$ & $214(26.6 \%)$ \\
\hline
\end{tabular}

When the news of this massive migration during July and August 1863 reached England, Colonial Secretary Lord Newcastle commented that "it is interesting to see emigration setting in from overpeopled Barbados to its under-peopled neighbours." 43 In fact, as Governor Hamilton had previously made clear to Newcastle, Antigua was hardly "under-peopled" given its high population density of 337 people per square mile in $1861 .{ }^{44} \mathrm{Also}$ forgotten by

39. Walker to Newcastle, August 9, 1863, CO 28/196.

40. Antigua Times, August 13, 1863, p. 2.

41. Antigua Times, August 28, 1863, p. 3; Antigua Times, September 26, 1863, p. 2. In the wake of emancipation some Antiguan planters had actively encouraged family reunification as a means of securing a larger and more reliable workforce (Smith 1988:29-32).

42. MHA, October 6, 1863, p. 62.

43. Walker to Newcastle, August 9, 1863, CO 28/196.

44. Barbados in 1861 claimed a population density of 920 people per square mile (The Reports made for the Year 1861 to the Secretary of State having the Department of the Colonies. Part 1: West Indies and Mauritus, London, 1863, pp. 30, 75). 
Newcastle was the recurrent threat of drought in Antigua itself. At the very time when Antiguan planters were importing laborers from drought-stricken Barbados, they were themselves in the midst of an "alarming drought." 45

The conditions faced by the migrants from Barbados were expressed in a letter by the newly arrived James Bovell, a laborer at Delaps estate, encouraging his wife to join him in Antigua. Despite receiving half an acre of land to grow his own provisions, Bovell wrote that,

\begin{abstract}
our employer is to feed us for 6 months, as no food is on the estate nor in the ground. It is very dry, for months they have had no rain and everywhere is suffering for want of water. I shall be very glad to get you dear ... you must bring some corn flour, potatoes, limes, yams, peppers and some pepper sauce ... I am making out pretty well ... but it is hard, I only wish I had come down a few months ago. I like this place very much, and I hope we shall soon have rain to plant our ground ... ${ }^{46}$
\end{abstract}

In Barbados, rain would have given workers like Bovell renewed work on the estates, but in Antigua under contract of indenture which assured regular wages of two "bits" a day, he was more concerned that the change of weather would allow his own independent domestic cultivation.

\title{
COLONIAL RIVALRIES AND THE REDEFINITION OF MIGRANT LABOR TO BRITISH GUIANA AND JAMAICA
}

The news of Barbadian emigration to St. Croix and Antigua rapidly spread across the Caribbean during August 1863, encouraging other colonial governments to formulate their own immigration schemes. In British Guiana, reports of disorder and heavy emigration from Barbados were initially greeted by the Royal Gazette with the editorial comment that "here is a good opportunity for our neighbours of Suriname to procure immigrants." 47 As in Antigua, Barbadian events were rapidly incorporated into pre-existing debates and concerns, and the end of slavery in Suriname in July 1863 had generated considerable concern in British Guiana that the indentured immigrant workforce so expensively imported into the British colony would be poached by neighboring Dutch planters. ${ }^{48}$ Fears in British Guiana of desertion to Suriname resulted in the intensification of restrictions on movement between the two territories, the extension of indentureship terms for African immigrants, and the comprehensive consolidation of legislation on inden-

45. Antigua Times, August 22, 1863, p. 3.

46. Antigua Times, October 3, 1863, p. 3.

47. Royal Gazette, August 8, 1863, p. 2.

48. Royal Gazette, June 13, 1863, pp. 2-3. 
tured immigration. ${ }^{49}$ While several hundred Barbadians were recruited for estates in Suriname during 1863, they objected to labor conditions in the colony and were eventually sent on to British Guiana. ${ }^{50}$

A second debate which fundamentally shaped the efforts of authorities in British Guiana to develop new sources of migrant labor during the early 1860 s were the concerns stimulated by declining immigration from Maderia, Africa, and China (Rodney 1977:4). American debates during the Civil War over "contrabands," or the former slaves of the Confederate South, reanimated discussions in British Guiana on the possibility of settlements by African-American immigrants. However, like the privately sponsored efforts which followed emancipation, immigration schemes initially aimed at black Americans were rapidly redirected to focus on West Indian migrants (Moore 1987:44). After heated public debate over migration from the United States in 1862 , by late 1863 Guiana's government had decided to seek five hundred laborers from Barbados while also attempting to establish recruiting agencies in North America. ${ }^{51}$ Importantly, under the Ordinance of October 28, 1863, labor recruitment from the British West Indies and North America was to be funded by the colony's immigration fund in the same way as indentured immigration from Asia and Africa.

The governor of British Guiana promoting the 1863 ordinance was Francis Hincks, who had previously criticized indentured immigration while serving in Barbados. Reversing his early public position on immigration, Hincks wrote that "this Ordinance simply extends to the United States and to the British Colonies the same provisions which are in force with regard to other classes of immigration except as to the length of indenture, which is limited to three years." ${ }^{52}$ In seeking to extend British Guiana's well-developed system of indentured immigration to recruitment from within the region,

49. These restrictions even extended to Indian immigrants whose contracts of indenture had expired and who sought to migrate to Suriname as free labor (The Creole, September 23, 1863, p. 3).

50. "Rapport de la Commission envoyée à la Barbade pour étudier les moyens de diriger l'émigration des travailleurs de cette colonie vers la Martinique" (hereafter "Rapport de la Commission"), FM/Gen 148/1243, Centre des Archives d'Outre-Mer, Aix-en-Provence, France, p. 13; Roberts (1955:260) estimated that 1,200 Barbadians migrated to Suriname in the decade following 1863.

51. Hincks to Newcastle, November 18, 1863, CO 111/347.

52. Hincks to Newcastle, November 18, 1863, CO 111/347; An Ordinance to Provide for the Introduction of Immigrants from the British West Indies and from the Continent of North America, No 14 of 1863, The Official Gazette of British Guiana, 1863, p. 15067. Both the United States and West Indies were also identified as sources of indentured immigrants in Suriname during the same year (Ordinance Concerning the Control and the Introduction of Free Laborers into Suriname, March 19, 1863, No. 71). 
Hincks argued he was merely following the example of Antigua which had also contracted Barbadians under indentures of three years. Anticipating the enactment of the new ordinance, Hincks commissioned Barbadian Edward Walcott to act as immigration agent for the colony and to recruit workers on three-year contracts, giving preference to families who sought to migrate. ${ }^{53}$

Significantly, this conception of state-controlled immigration from the Americas generated considerable opposition within British Guiana. Many merchants in the colony, whose interests lay in American trade and shipping, argued that the new migration from North America should be recruited privately rather than by the state. The mayor of Georgetown called a public meeting on the same day that the new immigration ordinance was promulgated (October 28, 1863) to organize a petition in favor of free immigration by black Americans without the costs of immigration agents or constant state regulation. At the public meeting, the leading speaker for free immigration was Frederick Winter, who rejected the new ordinance as too cumbrous, and called instead for a privately organized system of bounty immigration with no indenture contracts. ${ }^{54}$ Winter estimated that each migrant from Barbados would cost 25 dollars under an indenture of three years compared to only 5 dollars for passage as a free migrant. He argued "that although you may find the Barbados immigrant ready enough to indenture, you will find him equally ready to shake off the indenture when he sees an opportunity ... we will not get three months work from him." 55 Winter's scheme of private immigration was strongly opposed by Governor Hincks, who believed that indenture gave security of employment to both the employer and employee, as well as ensuring the state an important regulatory role. Hincks also argued that Winter's plans enjoyed little support amongst the plantocracy of British Guiana who remained committed to indenture as one of their most important sources of labor..$^{56}$

However, at the same time as these internal criticisms from within British Guiana, Hincks found his indentured scheme for West Indian migration

\section{MHA, November 3, 1863, p 108.}

54. The Creole, October 30, 1863, p. 2.

55. The Creole, October 30, 1863, p. 3; Similar reasoning was given in Trinidad, where the Port of Spain Gazette argued that there was no need for state-sponsored migration from Barbados for two reasons: "the immigrants helped over by private people are more likely to be of the right sort and to settle down to steady labour, than any that could be collected by Government agency ... we think that the immigration fund ought to be restricted to bringing in labourers, whose services can with moderate certainty be secured for estates work by indenture. Such indenture we maintain to be practically futile in the case of any labourers brought here from Barbados" (extract reproduced in the Royal Gazette, December 8, 1863, p. 3).

56. Hincks to Newcastle, November 18, 1863, CO 111/347. 
threatened by the changing policies of the Barbados government. In early October 1863, Governor Walker had publicly defended the emigration of two thousand Barbadians in less than two months. Addressing the Barbados House of Assembly, Walker detailed the movements to St. Croix and Antigua, before arguing that "for the present there is reason to believe that Emigration to both these places has ceased and the abstraction of labour which these lists represent with so dense a population as ours, is absolutely imperceptible." ${ }^{57}$ To the Colonial Office in London, Walker had earlier dismissed the departure of 1,400 laborers in August with the remark "we can very well spare them," while even in late October he wrote of "a moderate Emigration to the neighbouring Islands." 58 In November 1863, Governor Walker reversed his position on the mass emigration which had begun only four months earlier. Fearing that British Guiana's migration scheme would result in an exodus, the temporary tolerance of immigration agents and signing-on bonuses in Barbados was officially ended. Also underpinning Walker's change of policy was the promise of a new record sugar crop in 1864, and the "electric effect" of "the sudden rise in the value of sugar." 59

Significantly, Barbadian authorities at the end of 1863 framed their rejection of migration under contract with the language of free labor and social dislocation. In refusing to allow the immigration agent for British Guiana to commence recruiting, Governor Walker argued that "there is now sufficient employment for all hands, while the system of bounties upon which the whole operation rests is beginning to unsettle the minds of the peasantry and is disturbing their ordinary habits of industry." 60 Significantly, the bounties that were the focus for Walker's criticisms were in fact bonuses given to the workers themselves as an incentive to commit to long-term contracts, while the long-established principles to which he referred originated in the very different bounty systems paid by Trinidad and Guiana to ships' captains and immigration agents as commission to recruit migrant laborers in the wake of emancipation (Richardson 1980:400-1).

Equally, Walker claimed that the emigration of nearly three thousand laborers had resulted in a significant labor shortage in Barbados, despite its extreme population density. ${ }^{61}$ The emigration of adult males had resulted in the desertion of wives and children, the abandonment of the elderly and

57. MHA, October 6, 1863, p. 62.

58. Walker to Newcastle, September 25, 1863, CO 28/197; Walker to Newcastle, October 21, 1863, CO 28/197.

59. Royal Gazette, December 8, 1863, p. 2; The Times, August 18, 1863, p. 2.

60. Walker to Newcastle, November 7, 1863, CO 28/197.

61. Walker argued that of an estimated 34,000 field laborers, 10,000 were women and only half of the remainder were able bodied, and of these far fewer were reliable workers (Walker to Newcastle, November 23, 1863, CO 28/197). 
infirm. ${ }^{62}$ Such rhetoric was undercut by Walker's own emigration statistics (see Table 1), which revealed that a substantial component of such movements was migration by women and by families. Fueled by such arguments, a new act to amend the laws relating to emigration from Barbados was passed by the local Assembly at the start of 1864, explicitly targeting "the appointment of Agents who are to act upon the bounty system."63 British authorities insisted that the local act be amended to allow private parties to recruit labor, and to revoke the absolute ban on signing-on bonuses. ${ }^{64}$ However, during 1864, the Colonial Office in London allowed the Barbados government to reject immigration schemes from British Guiana, Antigua, St. Croix, and Jamaica. ${ }^{65}$

Faced with British Guiana's efforts to recruit Barbadian migrants, Governor Walker had complained to his superiors in Britain that,

I am quite sure that if this intercine system of enticing laborers from one British West India Colony to another were to be legalized, it would be the signal of such disquiet and ill blood in these parts. So far from being advantageous to the laborer, my opinion is that it would only tend to unhinge and destroy the little industrial character that belongs to him. ${ }^{66}$

In fact, the competition between colonies for migrant labor directly fueled a redefinition of regional immigration from indentured to free labor. Unable to recruit Barbadian laborers with a state-subsidized bounty for a threeyear contract of indenture, Governor Hincks changed his instructions to his immigration agent Walcott to offer free passage to British Guiana and the choice of employer for a six-month contract. ${ }^{67}$ Just as Walker had adopted

62. Walker to Newcastle, November 7, 1863, CO 28/197; The following passage significantly appeared in the "Crime" section of the 1863 Blue Book for Barbados: "The tendency of the Emigration to which I have referred in a former part of this paper is of course to take away the able bodied laborer, and to leave upon our hands the old, the infirm, the sickly, and the young. And the numberless cases of distress and destitution which now present themselves are in 19 cases out of 20 , or even in a larger proportion owing to desertion by parents and other natural protectors who have left the Island. The recent Emigration to Demerara has been particularly fruitful of such cases, when we hear of the teeming population of Barbados therefore, people must not jump to the conclusion that it consists only of a redundancy of labor" (Walker to Cardwell, October 31, 1864, CO 29/199).

63. Walker to Newcastle, April 19, 1864, CO 28/198.

64. Walker to Cardwell, October 6, 1864, CO 28/199.

65. Copy August 8, 1864, Walker to Birch, August 12, 1864, CO 28/198.

66. Walker to Newcastle, November 23, 1863, CO 28/197.

67. Hincks provocatively stated that restrictions on indentured workers in British Guiana were "not practically much, if at all, greater than those imposed on those labourers in Barbados who reside on Estates" (Walker to Newcastle, November 23, 1863, copy November 7, 1863, Hincks to Walker, CO 28/197). 
the language of free labor in seeking to curtail bounty-based recruitment, now Hincks deployed the same rhetoric to justify the importation by the colonial state of Barbadian workers.

Hincks's scheme of free labor migration resulted in a new surge of emigration to British Guiana following the summer harvest of 1864. By the end of September 1864, it was estimated that almost 2,800 Barbadian migrants had arrived in British Guiana, over 80 percent of whom were adults. ${ }^{68}$ While these migrants received the same "comforts and medical care" as indentured immigrants, their shorter contracts marked the origins of a new seasonal workforce whose circular migration was shaped by the distinct rhythms of harvest in Barbados and British Guiana. ${ }^{69}$ Differences in rainfall meant that crop time (when wages were highest and employment most available) was spread between January and June in Barbados, whereas in Guiana this occurred between September and December (Levy 1980:10; Rodney 1981:4, 48; Watts 1987:176). The environmental contrasts between the two colonies were reinforced during the 1870 s by factory modernization in British Guiana, such as the adoption of vacuum-pan and centrifugal technologies, which intensified the seasonal need for cane cutters during a concentrated harvest period.

Walter Rodney (1981:31-59) has shown how the expansion of plantation production in British Guiana during the late nineteenth century was fueled by increasingly specialized migrant labor forces. While indentured Indians resident on the sugar estates were responsible for the daily cultivation of the crop, the escalating demands of harvest fueled the seasonal migration of Barbadians as skilled cane cutters. Such segmentation of plantation employment meant that Barbadians claimed the highest-paying tasks, while their departures after the harvest enabled them to avoid the increased disease rates of the wet season (Johnson 1973:12-16). Between 1863 and 1875, the government of British Guiana subsidized the passage of an estimated 21,000 emigrants from Barbados, and it was not until the severe economic depression of 1885 that Hincks's scheme for Barbadian labor was abandoned (Rodney 1977:4-5).

As Barbadian immigration to Guiana intensified in late 1864, several Kingston merchants were promoting their own scheme for Barbadian immigration to Jamaica. Working from privately raised funds, a Jamaican agent was able to recruit 150 migrants who left Barbados at the end of August 1864 on the ship Swordfish..$^{70}$ These migrants were promised wages of up to a dollar a day in Jamaica, and they were encouraged by the availability of land at prices as low as five dollars an acre. The scheme echoed Jamaican

68. The Morning Journal, October 28, 1864, p. 3.

69. The Morning Journal, September 23, 1864, p. 2.

70. The Morning Journal, September 6, 1864, p. 2. 
experiments with European immigration in the 1830s, for as one observer in Barbados, reported, "the Principle upon which the Jamaican emigration is conducted, apply rather to the occupancy of uncultivated land than to the supply of labor for sugar estates." ${ }^{\prime 11}$ From Barbados, migrants traveled without contracts, although they were committed to repaying their passage money and any other advances of funds they had received. ${ }^{72}$ The Jamaican immigration scheme therefore contrasted to other recruitment efforts in Barbados because of its initial private sponsorship, the absence of a contract, and the intended employment for the immigrants..$^{73}$ Significantly, this migration never became the influx of laborers desired by Jamaican authorities, as the decision of the local legislature and Jamaica's governor, Edward Eyre, to financially support the recruitment, was used by the governor of Barbados to declare the agent's activities illegal. ${ }^{74}$

Amongst the emigrants to Jamaica at the end of 1864 was a group of mechanics and artisans from Christ Church (Barbados), who previously attempted to migrate to Liberia during the crisis of $1863 .^{75}$ To contemporaries, such as Governor Walker in Barbados, it seemed as though the absence of long indentures in Jamaica and British Guiana had changed the composition of migration from the island. ${ }^{76}$ When Francis du Bois visited Barbados seeking to restart indentured immigration to St. Croix in early September 1864 , Walker rejected his request by arguing that the continuing movements to Guiana and Jamaica were by skilled workers, "people about Town," and not field laborers. ${ }^{77}$ Walker's reasoning became enshrined as demographic

71. Du Bois to Birch, August 25, 1864, Koloniernes Centralbestyrelse (hereafter KC) \#909, Rigsarkivet, Copenhagen.

72. As one Jamaican newspaper proclaimed "neither they nor any of their fellow-countrymen will be under the control of immigration agents; they will be free settlers - free in every sense of the word, and subject only to the operation of laws which are enacted by the legislature for the general protection of society" (The Morning Journal, September 21,1864 , p. 2). Within two months of the Barbadians settling in the counties of Surry and Cornwall, there had been protest meetings in Port Royal by the Jamaican peasantry over the preferential treatment to free immigrants, while news had reached Barbados of the migrant's disappointment in Jamaican conditions (The Morning Journal, October 31, 1864, p. 2; The Morning Journal, September 21, 1864, p. 2; Du Bois to Birch, September 26, 1864, KC \#909).

73. These differences were perhaps due to the 1858 attempt in Jamaica to restart indentured immigration from India, as after the arrival of 4,646 Indians the scheme was canceled in early 1863 because planters were not able to bear the costs of recruitment and employment (Green 1986:175-76).

74. The Morning Journal, November 17, 1864, p. 3; Roberts 1955:255.

75. Royal Gazette, April 30, 1864, p. 3; Karch 2002:8.

76. Walker to Cardwell, October 31, 1864, CO 29/199.

77. Du Bois to Birch, September 9, 1864, KC \#909. 
fact when his successor, Governor Rawson (1872:9), completed a detailed census of the island's population in 1871. Certainly the shift away from indenture in 1864, drew other sections of Barbadian society into leaving the island, but Walker provided little evidence that such a change was as absolute as he claimed in denying further applications for migrant labor.

Frustrated by Walker's intransigent opposition to indentured recruitment for St. Croix, Du Bois examined the mass flow of migrants to British Guiana and wrote to his employers that

These terms are in no respect in accordance with our views on this subject, the emigrant $[s i c]$ receive no bounty, enter into no contract, and acting entirely by their own free will, no agent appears in the transaction, the parties conducting this supply of emigrants simply state the terms on which emigrants will be received on their arrival, and supply the vessels necessary for transport - and the redundant and suffering population of this island crowd the vessels daily to overflowing. ${ }^{78}$

In contrast, indentures remained a necessity for planters in St. Croix as their sugar harvest overlapped with Barbados, while they lacked the milling technology that made short seasonal migration possible for British Guiana. These material conditions resulted in the continued insistence on long-term labor contracts by the St. Croix plantocracy, so that unable to secure migrants in Barbados, their recruitment efforts turned after 1864 to the nearby British Leeward Islands (Tyson 1995:138-43).

Francis du Bois had arrived in Barbados in July 1864 confident of obtaining indentured immigrants from the island, however within two months that optimism had faded, and not simply because of Governor Walker's hostility. As du Bois wrote back to St. Croix, prospects for the recruitment of Barbadian laborers had declined by late September for "the season is too far advanced - food becoming abundant - labour more in demand."79 These profound seasonal changes in material conditions were central to the debates over migration from Barbados during the mid-1860s. Out of crop, conditions on the island were described as a Malthusian nightmare of overpopulation, underemployment, and food shortage. ${ }^{80}$ During harvest, the Barbados elite claimed that any emigration from the island would undermine the labor supplies need for sugar production. These rhythms of demographic debate in the British West Indies - of overpopulation and labor shortage - were themselves changing during the $1860 \mathrm{~s}$, as new milling technology concentrated the harvest in British Guiana and Trinidad, which generated new opportunities for seasonal migration.

78. Du Bois to Birch, August 25, 1864, KC \#909.

79. Du Bois to Birch, September 26, 1864, KC \#909.

80. "Rapport de la Commission," pp. 7-9. 
Focusing on the mass movements in the nineteenth century of Asian indentured immigrants to the Caribbean, historians have rarely examined the other attempts, experiments, and failed schemes for migrant labor in the region. Yet these projects often overlapped, so that at the same time that Francis Hincks promoted the codification of Indian immigration regulations in British Guiana, he also sought to extend indentureship to Barbados. Indenture terms were often transplanted from one migrant group to another, as government officials and planters sought new sources for immigration in the early $1860 \mathrm{~s}$ with the resources and attitudes accumulated during previous debates. However, this extension of indentureship to Barbadian migrants was rapidly undermined by the competition between the West Indian colonies over labor supply, by internal tensions within the different colonies over the cost and control of migrant labor, and by the agency of the migrants themselves. Ultimately, it was the failed attempts by Barbadian authorities in 1864 to block mass emigration from their island which marked a new divergence between currents of regional and indentured immigration in the British West Indies.

\section{REFERENCES}

BECKLES, HILARY MCD, 2004. Great House Rules: Landless Emancipation and Workers Protest in Barbados 1838-1928. Kingston: Ian Randle.

Bolland, O. NiGEL, 1981. Systems of Domination after Slavery: The Control of Land and Labour in the British West Indies after 1838. Comparative Studies in Society and History 23:591-619.

CARTER, HENDERSON, 1996. Food Riots and Labor Protest in Post-Slavery Barbados: An Analysis of the 1863 Riots. Unpubl. paper, Conference of the Association of Caribbean Historians, Barbados.

CURTIN, PHILIP D., 1955. Two Jamaicas: The Role of Ideas in a Tropical Colony, 18301865. Cambridge MA: Harvard University Press.

DEERR, NOEL, 1949. The History of Sugar, Vol. 1. London: Chapman and Hall.

—, 1950. The History of Sugar, Vol. 2. London: Chapman and Hall.

DYDE, BRIAN, 2000. A History of Antigua: The Unsuspected Isle. London: Macmillan.

FLETCHER, L.P., 1980. Barbados Emigration Policy from Emancipation to Independence, 1838 to 1936. Unpubl. paper, Conference of the Caribbean Studies Association, Curaçao.

Green, William A., 1986. Plantation Society and Indentured Labor: The Jamaican Case, 1834-1865. In P.C. Emmer (ed.), Colonialism and Migration: Indentured Labour Before and After Slavery. Dordrecht, the Netherlands: Martinus Nijhoff, pp.163-86. 
Hall, Douglas, 1971. Five of the Leewards, 1834-1870: The Major Problems of the Postemancipation Period in Antigua, Barbuda, Montserrat, Nevis and St Kitts. Barbados: Caribbean Universities Press.

HIGMAN, B.W., 1982. Slavery and the Development of Demographic Theory in the Age of the Industrial Revolution. In James Walvin (ed.), Slavery and British Society 17761846. Baton Rouge: Louisiana State University Press, pp. 164-94.

HINCKS, FRANCIS, 1859. The Results of Negro Emancipation: A Speech delivered at a Public Meeting held in London, August 1 1859: The Twenty-fifth Anniversary of the Abolition of Slavery by the Parliament of Great Britain. n.p.

JOHNSON, HOWARD, 1973. Barbadian Immigrants in Trinidad, 1870-1897. Caribbean Studies 13(3):5-30.

KarCH, CeCilia, 2002. The Pull of the Fatherland: Migration of Barbadians Back to Africa in the 1860s. Unpubl. paper, Conference of the Association of Caribbean Historians, Bahamas.

LAURENCE, K.O., 1965. The Evolution of Long-Term Labor Contracts in Trinidad and British Guiana 1834-1863. Jamaican Historical Review 5:9-27.

-, 1971. Immigration into the West Indies in the $19^{\text {th }}$ Century. Barbados: Caribbean Universities Press.

LEVY, Claude, 1980. Emancipation, Sugar, and Federalism: Barbados and the West Indies, 1833-1876. Gainesville: University Presses of Florida.

LOOK LAI, WALTON, 1993. Indentured Labor, Caribbean Sugar: Chinese and Indian Migrants to the British West Indies, 1838-1918. Baltimore: Johns Hopkins University Press.

Lowenthal, DaVID, 1957. The Population of Barbados. Social and Economic Studies 6:445-501.

MARSHALL, DAWN, 1984. Migration within the Eastern Caribbean, 1835-1980. Unpubl. paper, Conference on Cultural Contacts and Migration in the Caribbean, Barbados.

MoORe, Brian, 1987. Race, Power and Social Segmentation in Colonial Society: Guyana After Slavery, 1838-1891. New York: Gordon and Breach.

NORTHRUP, DAVID, 1995. Indentured Labor in the Age of Imperialism, 1834-1922. Cambridge: Cambridge University Press.

RAWSON, R.W., 1872. Report upon the Population of Barbados, 1851-1871. Barbados: n.p.

RICHARDSON, BONHAM, 1980. Freedom and Migration in the Leeward Caribbean, 1838-48. Journal of Historical Geography 6:391-408.

RoBERTS, G.W., 1955. Emigration from the Island of Barbados. Social and Economic Studies 4:245-88. 
RoDNEY, WALTER, 1977. Barbadian Immigration into British Guiana 1863-1924. Unpubl. paper, Conference of the Association of Caribbean Historians, Barbados.

—, 1981. A History of the Guyanese Working People, 1881-1905. Baltimore: Johns Hopkins University Press.

SeWell, William G., 1862. The Ordeal of Free Labor in the British West Indies. London: Sampson Low. [Orig. 1861.]

SHERIDAN, RICHARD B., 1989. Changing Sugar Technology and the Labor Nexus in the British Caribbean, 1750-1900, with Special Reference to Barbados and Jamaica. New West Indian Guide 63:59-93.

SIRCAR, K.K., 1971. Emigration of Indian Indentured Labor to the Danish West Indian Island at St Croix, 1863-68. Scandinavian Economic History Review 19(2):136-37.

SMith, K.B. \& F.C. SMith (eds.), 1988. To Shoot Hard Labor: The Life and Times of Samuel Smith, an Antiguan Workingman 1877-1982. Toronto: Edan's Publishers. [Orig. 1986.]

TINKER, HuGH, 1993. A New System of Slavery: The Export of Indian Labour Overseas, 1830-1920. London: Hansib. [Orig 1974.]

TYSON, GEORGE, 1995. "Our Side”: Caribbean Immigrant Laborers and the Transition to Free Labor on St Croix, 1848-79. In Karen Fog Olwig (ed.), Small Islands, Large Questions: Society, Culture \& Resistance in the Postemancipation Caribbean. London: Frank Cass, pp. 135-60.

WATSON, KARL, 2000. "Walk and Nyam Buckras": Poor White Emigration from Barbados, 1834-1900. Journal of Caribbean History 34:137-46.

WATTS, DAVID, 1987. The West Indies: Patterns of Development, Culture and Environmental Change since 1492. Cambridge: Cambridge University Press.

\section{LAURENCE BROWN}

Centre for Cross-Cultural Research

Australian National University

Old Canberra House, Canberra

ACT 0200, Australia

$<$ Laurence.Brown@anu.edu.au $>$ 
